\title{
The mismatch between the unmet need for and supply of occupational English skills: an investigation of higher educated government staff in Norway
}

\author{
Glenn Ole Hellekjær ${ }^{1}$ - Tone Fairway $^{1}$
}

Published online: 10 April 2015

(C) The Author(s) 2015. This article is published with open access at Springerlink.com

\begin{abstract}
Nordic universities are involved in a global competition against American and UK universities, whose main competitive advantage is their placement in English-speaking countries. The authors argue that Nordic universities need to do more to offset this advantage than merely offer English-Medium (EM) courses to foreign and domestic students. They also need to systematically address their students' need for advanced occupational English skills. To underpin this claim, the authors use data from three different needs analyses: (1) a large-scale survey of language use and needs in Norwegian government ministries, (2) a qualitative follow-up study based on interviews of state directorate staff, and (3) a follow-up survey of ministerial job advertisements. These show that while almost $89 \%$ of ministerial staff use English at work on a regular basis, almost $80 \%$ of the highly educated staff have no formal English courses beyond upper secondary school, and that this leads to communication problems. The job advertisement data show that this is because language skills are invariably required in combination with professional degrees that do not necessarily include language modules. It concludes by arguing the need to integrate language-learning goals into EM courses and to supplement these with occupational English and communication courses.
\end{abstract}

Keywords English for occupational purposes - Higher education · Needs analysis · Language needs

Glenn Ole Hellekjær

g.o.hellekjar@ils.uio.no

Tone Fairway

Tone.Fairway@ude.oslo.kommune.no

1 Department of Teacher Education and School Research, University of Oslo,

P.O. Box 1099, Blindern, 0317 Oslo, Norway 


\section{Introduction}

Institutions of higher education are involved in a national and global competition in which prestigious American and UK universities' most important competitive advantage is their placement in English-speaking countries (Marginson 2006). To compete, Nordic research universities and other institutions (Marginson 2006, p. 21) have adopted a strong focus on internationalization that involves research, international staff and student recruitment, and on offering English-Medium (EM) courses and programs to foreign and domestic students (see also Hughes 2008).

We argue that this might be a quite inadequate response. First, as Fabricius, Mortenson, and Haberland (this issue) point out, the increased use of English in itself does not guarantee a competitive edge, nor indicate quality. Furthermore, the importance of English language skills has hardly been recognized as a vital component in this strategy (Saarinen and Ursin 2012). This stands in contrast to some institutions in English-speaking countries that are discussing the need to enhance their international students' language learning as part of their stays and studies (Arkoudis 2013). Indeed, in a Knowledge Society and Knowledge Economy perspective (Välimaa and Hoffman 2008), English in the Nordic countries appears as a more or less invisible—or taken for granted-skill. One might even ask if English is looked upon as what economists term a "public good"-this because it is provided free of charge by the educational system and therefore taken more or less for granted (Grin et al. 2010).

The aim of the present mixed-methods study is to show that there is an unmet need for occupational English skills, and, to argue that Nordic universities should compete internationally by providing English modules as part of their professional degrees. To support our arguments, we use data from three needs analyses (NAs) in Norwegian ministries and directorates: (1) a large-scale survey of language use and needs in Norwegian government ministries (Hellekjær 2010), (2) a qualitative, follow-up study based on interviews of state directorate staff (Fairway 2011), and (3) a follow-up survey of ministerial job advertisements (Hellekjær and Hellekjær 2015). We use data from these three studies to investigate:

(a) the extent of English language use in an occupational context,

(b) the degree to which the respondents experience language difficulties,

(c) the gap between respondents' education and qualifications in English, and

(d) how English skills are required in job advertisements

Data from Hellekjær (2010) are used to answer a and c, from Hellekjær (2010) and Fairway (2011) to answer b, and from Hellekjær and Hellekjær (2015) to answer d. Next, we use data from studies of government ministries and directorates to highlight the relation between occupational English needs, job categories, and language requirements in job advertisements.

\section{Needs analyses and occupational English proficiency}

Norwegians, as well as Swedes, Danes, and Finns, are reputedly quite proficient in English (Bonnet 2004; Education First 2013). In Norway, English is a compulsory subject from first grade to upper secondary school. There is also extensive media exposure to English, although its impact on language learning is difficult to quantify (Rindal 2010). In fact, the position of English is so strong in Norway, as in the other Nordic countries that Graddol (2007) argues 
that it is close to being a second language. Indeed, in Finland, it is even referred to as a third domestic language in addition to Finnish and Swedish (Leppänen et al. 2008). However, there is reason to argue that this high level of proficiency does, nonetheless, not provide the advanced and specialized proficiency required in occupational contexts (Fairway 2011; Hellekjær 2007a, 2010, 2012; Hellekjær and Hellekjær 2015).

In the present study, we define NAs as "the processes involved in gathering information about the needs of a particular client group in industry or education" (Brown 2009, p. 269). Early language NAs tended to focus on "discrete language items of grammar and vocabulary” (Dudley-Evans and St. John 1998, p. 122). Starting with Munby (1978) and Richterich and Chancerel (1978), NAs have focused on identifying language functions and situations for language use (Dudley-Evans and St. John 1998; Hutchinson and Waters 1987; Long 2005).

Dudley-Evans and St. John (1998) and Long (2005) have addressed validity issues, in the sense that the many, predominantly quantitative NA studies are reliable decisionmaking tools. Dudley-Evans and St. John (1998) and Long (2005) therefore argue in favor of using mixed-methods research designs (Teddlie and Tashakkori 2009) that utilize multiple sources and methods to provide richer data and ensure validity (e.g., Jasso-Aguilar 2005; Long 2005).

A number of NAs examine the role of English as a Lingua Franca (ELF) and Business English as a Lingua Franca (BELF), (e.g., Jenkins et al. 2011), or English for Business Communication (Bhatia and Bremner 2012). The international BELF NAs for the most part examine the use of English for business communication purposes by non-native speakers (Charles 2006; Ehrenreich 2010a, b; Jenkins et al. 2011; Kankaanranta and Louhiala-Salminen 2010; Kankaanranta and Planken 2010; Louhiala-Salminen et al. 2005; Louhiala-Salminen and Kankaanranta 2011; RogersonRevell 2007, 2010; Sweeney and Hua 2010). In engineering, there is also a recent and quite comprehensive Finnish study of language needs by Huhta (2010). The NAs all find that language skills are needed in combination with a professional degree: "language skills without the necessary professional profile are not sufficient" (Ehrenreich 2010a, b, p. 417). They also show that English-in combination with first language (L1) skills-is an absolute must in business (Charles 2006; Ehrenreich 2010a, b; Rogerson-Revell 2007).

From the public sector, there are few international NA studies. Most are from the USA and focus on the need for other languages than English (e.g., Brecht and Rivers 2005; Clifford and Fischer 1990; Herzog 2003; Lett 2005; Tare 2006).

With regard to Norwegian NAs, the majority have been quantitative surveys of language needs in business (e.g., Hellekjær 2007a, 2012; Hellum and Dypedahl 1998; Norges Handelshøyskole 1973; Lie and Skjoldmo 1982). Kvam and Schewe (1984), and Vold and Doetjes (2012), have examined job advertisements. There has also been a qualitative study of Norwegian subsidiaries in Belgium (Gundersen 2009).

These studies show that the most common foreign languages used are, in descending order of importance: English, German, French, and Spanish. They also reveal an increasing, and perhaps excessive, reliance on English (see Hellekjær and Hellekjær 2014).

The job advertisement NAs of Kvam and Schewe (1984) and Vold and Doetjes (2012) found that employers consistently specify English and/or L3 skills in combination with a professional degree, such as engineering, business administration, economics, or law. Vold and Doetjes (2012) also found that employers often neglect mentioning language skills even when it was clear from the advertisements that these would be necessary. 
There have been three public sector NAs in Norway, Hellekjær's (2010) quantitative survey from government ministries, Fairway's (2011) qualitative follow-up study from government directorates, while a third by Hellekjær and Hellekjær (2015) analyzes ministerial job advertisements as a follow-up to Hellekjær (2010). These show the same trends as do the business NAs; the extensive, often daily use of English, and that English skills, when mentioned, are invariably required in combination with professional degrees. They also show that ministries, as do businesses, lack staff with the advanced English proficiency needed to master demanding communication situations (Fairway 2011; Hellekjær 2007a, 2010, 2012). This gap is further investigated in the present study.

\section{Method}

The data in the following analyses were, as mentioned above, drawn from three different studies that we, as suggested by Dudley-Evans and St. John (1998) and Long (2005), triangulated to provide richer and more detailed data and to improve validity. The first, Hellekjær (2010) is a quantitative survey of ministry employees that uses a quasi-experimental, one-group, posttest research design (Shadish et al. 2002, pp. 106-107). The second, Fairway (2011) is a qualitative, follow-up study using semi-structured interviews with 13 staff from three Norwegian state directorates. The third (Hellekjær and Hellekjær 2015), which was designed as a follow-up of Hellekjær (2010), is a quantitative survey of 485 ministerial job advertisements.

Table 1 Overview of respondents according to ministry and language use

\begin{tabular}{llll}
\hline Ministry & All & L1 only & English \\
\hline Ministry of labor & 68 & 8 & 60 \\
Ministry of children, equality and social inclusion & 30 & 3 & 27 \\
Ministry of finance & 59 & 5 & 54 \\
Ministry of fisheries and costal affairs & 21 & 0 & 21 \\
Ministry of government administration, reform and church affairs & 35 & 6 & 29 \\
Ministry of defense & 76 & 7 & 69 \\
Ministry of health and care services & 47 & 6 & 41 \\
Ministry of justice & 60 & 11 & 49 \\
Ministry of local government and regional development & 43 & 11 & 32 \\
Ministry of culture & 36 & 6 & 30 \\
Ministry of education and research & 81 & 13 & 68 \\
Ministry of agriculture and food & 39 & 4 & 35 \\
Ministry of the environment & 45 & 2 & 43 \\
Ministry of trade and industry & 48 & 3 & 45 \\
Ministry of petroleum and energy & 25 & 1 & 24 \\
Ministry of transport and communications & 33 & 3 & 30 \\
Ministry of foreign affairs & 96 & 5 & 91 \\
The office of the prime Minister & 4 & 4
\end{tabular}

$N=846$ 
Hellekjær (2010) is an online survey of 845 employees in 18 government ministries and the Prime Minister's office. The online questionnaire comprised 76 items about educational backgrounds, about language used and frequency of use, and about any language difficulties encountered. There was also a final open-ended question. Rambøll Management AS carried out the survey.

Out of the initial, randomly selected sample of 1551 out of about 4225 ministerial employees, 845 answered. This gave a $55 \%$ reply rate and a sample comprising $19 \%$ of the ministerial employees. Table 1 provides an overview of the sample according to ministry. It also provides an overview of the percentage that use English at work, or those who only use Norwegian (L1).

As can be seen, 751 (89\%) of the respondents used English at work. Several of the 94 $(11 \%)$ who only used Norwegian mentioned that this depended on their current job and was subject to change.

The next study, Fairway (2011), is a qualitative, Master's level study of the use of English in three different state directorates. Two of these focused on domestic issues, the third almost entirely on international. The sample was gathered by contacting the human resources departments in three directorates and asking for help to get in touch with English speakers in different departments. Fairway's goal was a purposive sample that was as "varied as possible in such a limited sample, in that they represent three different directorates and different departments as well as different levels of responsibilities within their departments" (Fairway 2011, p. 30). She noted that the 13 informants who volunteered were positive and quite interested in the topic. Their backgrounds were also quite comparable to the ministerial staff surveyed by Hellekjær (2010), since about $85 \%$ of the directorate informants were highly qualified professionals in various areas with more than 4 years of higher education, compared to the $95 \%$ in Hellekjær (2010) (see Table 2). While all of the informants used English at work, $81 \%$ had upper secondary (Table 3) school English qualifications only, almost the same as the $80 \%$ in Hellekjær (2010) (see Table 4 below).

The semi-structured interview guide comprised questions on (1) Background and qualifications, (2) Use of English in the workplace, (3) Specific examples of situations where the use of English or foreign languages either works successfully or fails, (4) The quality control of the work performed in English or another foreign language, and (5), the need for Continual Professional Development (CPD) courses. The interviews were conducted in Norwegian and the quotes translated by Hellekjær.

The third study, Hellekjær and Hellekjær (2015) is a needs analysis based on 485 job advertisements from Norwegian government ministries, advertised between January 1 and June 30 in 2012 and then again in 2013. The second period was included to enlarge the study. The aim was to identify to what extent English and L3 language skills are explicitly required. It comprises all job advertisements from government ministries appearing in Norway's largest newspaper, Aftenposten. Relevant supplementary information was then downloaded from the online version of the job advertisements (see http://www.regjeringen. no/nb/aktuelt/ledige-stillinger-i-departementene.html?id=451314). Key data were coded in SPSS, such as position, ministry, qualifications, whether language skills were specified, and to what extent international relations were explicitly mentioned.

The advertisements themselves were in Norwegian, and varied in length from two or three paragraphs to more than 500 words depending on the position. They started with a general description of the position and the area of responsibility. This was followed by a closer description of the tasks, then by a listing of the required qualifications-where 
Table 2 Overview of positions advertised from 1 January to 30 June in 2012 and 2013, according to ministry

\begin{tabular}{|c|c|c|c|}
\hline \multirow[t]{2}{*}{ Ministries } & \multicolumn{3}{|c|}{ Number of positions advertised } \\
\hline & 2012 & 2013 & Total and percent \\
\hline Ministry of labor & 11 & 18 & $29(6)$ \\
\hline Ministry of children, equality and social inclusion & 14 & 9 & $23(5)$ \\
\hline Ministry of finance & 10 & 5 & $15(3)$ \\
\hline Ministry of fisheries and costal affairs & 11 & 5 & $16(3)$ \\
\hline Ministry of government administration, reform and church affairs & 24 & 18 & $42(9)$ \\
\hline Ministry of defense & 11 & 18 & $29(6)$ \\
\hline Ministry of health and care services & 12 & 8 & $20(4)$ \\
\hline Ministry of justice & 33 & 30 & $63(13)$ \\
\hline Ministry of local government and regional development & 20 & 20 & $40(8)$ \\
\hline Ministry of culture & 7 & 8 & $15(3)$ \\
\hline Ministry of education and research & 23 & 9 & $32(7)$ \\
\hline Ministry of agriculture and food & 8 & 8 & $16(3)$ \\
\hline Ministry of the environment & 16 & 27 & $43(9)$ \\
\hline Ministry of trade and industry & 28 & 9 & $37(8)$ \\
\hline Ministry of petroleum and energy & 7 & 10 & $17(3.5)$ \\
\hline Ministry of transport and communications & 13 & 3 & $16(3)$ \\
\hline Ministry of foreign affairs & 10 & 14 & $24(5)$ \\
\hline The office of the prime minister & 4 & 4 & $8(2)$ \\
\hline Total & 262 & 233 & $485(100)$ \\
\hline
\end{tabular}

$n=485$

Table 3 General level of education among using ministerial respondents using English from Hellekjær (2010)

$n=751$

\begin{tabular}{lcc}
\hline General education & Respondents & In percent \\
\hline Primary and secondary education & 25 & 3 \\
Undergraduate courses or degrees & 92 & 12 \\
Graduate courses or degrees & 621 & 83 \\
In-service education & 13 & 2 \\
Total & 752 & 100 \\
\hline
\end{tabular}

language skills were or were not specified, next an overview of pay offered and other benefits, and finally one or two people who could be contacted for further information.

The coding was sometimes made difficult through vague formulations referring to communication skills or language skills in general. Only when English skills were explicitly required were they coded as such. An overview of the advertisements according to ministry is provided in Table 2.

There are 485 advertisements altogether. The 262 positions from 2012 represent about $6 \%$ of the about 4225 positions in the ministries and the 233 in 2013 about $5 \%$. Since these represent almost all of the ministerial positions advertised over two six-month periods, this sample should be able to provide useful information about the types of positions advertised, and to what extent English skills are specified. We are aware that job advertisements are constructed on the basis of various terms and conditions, such internal 
Table 4 Overview of the respondents' English qualifications from Hellekjær (2010). The distribution is based on the 751 respondents who use English, with seven missing answers

\begin{tabular}{lcl}
\hline English qualifications/education & Respondents & In percent \\
\hline Primary education & 7 & 1 \\
Upper secondary education & 599 & 80.5 \\
Undergraduate/graduate courses or degrees & 138 & 18.5 \\
Missing & 7 & 1 \\
Total & 744 & 100 \\
\hline
\end{tabular}

$n=751$

discussions and compromises with regard to needs, legislation on open recruitment of civil servants, informal and open recruitment, or as we touch upon below, expectations based on previous experience. These are issues we have not been able to deal with here, but which we are planning to do in a separate, follow-up study. Some caution is therefore merited in the interpretation of the advertisement data in the present study.

With regard to validity, one of the main strengths of the two first NAs (Hellekjær 2010; Fairway 2011) is that the respondents answer on the basis of their personal experiences of using English, not on behalf of colleagues or an organization, which is often a source of error (Reeves and Wright 1998, p. 38). Another is that the main study, Hellekjær (2010), is based on a reasonably representative sample of 846 ministerial staff, $55 \%$ of the about 1500 employees contacted. These findings are in turn supported, and explained, by Fairway's interviews with directorate staff, as well as by the survey of 485 job advertisements. Furthermore, as we will return to in the discussion, the findings in these studies reflect those in other, international and Norwegian studies. All in all, we would therefore argue that the present study provides a valid picture of the need for English skills among educated professionals.

\section{Results and analysis}

In the following, results are presented in three subsections. In the first, we present the findings from Hellekjær (2010). The second presents interview data from Fairway (2011). The third subsection comprises the analysis of the job advertisement data from Hellekjær and Hellekjær (2015).

\section{Hellekjær (2010)—language backgrounds}

International as well as Norwegian business NAs reveal that most occupational English users are highly educated, with professional degrees such as in engineering, business economics, public administration, or in law or marketing. This was also the case for the respondents from the Norwegian ministries.

As is displayed, $95 \%$ of the ministerial respondents have university or college degrees, of which the great majority $(83 \%)$ is at the graduate level.

Next, as can be seen in Table 1, the great majority $751(89 \%)$ of the respondents used English at work while $94(11 \%)$ used Norwegian only. The following analysis will focus on the English-using subsample. 
With regard to qualifications in English, business NAs indicate that professional degrees do not always include English modules, and consequently, employees are often forced to rely on their upper secondary school language skills, although for Norway precise numbers have not been available. Therefore, Hellekjær (2010) included items about formal and informal English qualifications. The data on formal English qualifications are provided below.

As shown in Table 4, about $80 \%$, of the ministerial respondents who use English at work, rely on their upper secondary school English qualifications. Only $18.5 \%$ have formal qualifications from higher education. However, the data in Table 5 show that a substantial number also have in-service courses, other forms of training, or have studied in an English-speaking country. In addition, many will probably have experienced extensive and informal, on-the-job language learning, which was not touched upon in the survey.

To sum up so far, the great majority of the highly educated respondents have no formal English qualifications beyond their upper secondary school courses. A considerable number, however, have had the opportunity to improve their English skills through other means. This would indicate great variation in their language proficiency-which will be examined in the next section.

\section{Are there language or communication problems?}

English is used in a variety of work-related situations ranging from informal and not necessarily demanding tasks such as telephone calls, conversations, or e-mails to formal, specialized, and linguistically challenging tasks such as negotiations, discussions, presentations, and press conferences. Table 6 provides an overview of how often and for which tasks the ministerial respondents use English.

This overview shows that reading work-related texts in English is by far the most frequent activity, followed by simple oral communication. It is not unexpected that the more formal and demanding communication situations and tasks occur less frequently. Indeed, some respondents only rarely or never take part in such communication. However, a substantial number of the 751 respondents use English frequently, and that many also use it in demanding spoken and written communication situations.

We also asked to what extent the respondents have experienced that inadequate English has led to communication difficulties. The results are presented in Table 7.

These answers leave some uncertainty with regard to interpretation. On the one hand, it might not be likely that a professional organization experiences frequent and serious communication problems, as it is possible to replace or retrain those who cause or contribute to the difficulties. Alternatively, the difficulties may be due to the other party being weak in English, and it might be the other party whose proficiency is weak. Or, as the

Table 5 Other qualifications in English. Several answers are possible from Hellekjær (2010)

\begin{tabular}{lcc}
\hline Other qualifications in English & Respondents & In percent \\
\hline In-service courses & 201 & 27 \\
Language courses abroad & 132 & 18 \\
Non-language, university level courses taught in English & 223 & 30 \\
6 Months or longer stays in English-speaking countries & 257 & 34 \\
English is my mother tongue (L1) & 4 & $<1$ \\
\hline
\end{tabular}

$n=751$ 
Table 6 How frequently do you use English, orally or in writing, for the following situations and tasks? From Hellekjær (2010)

\begin{tabular}{lllllll}
\hline & $\begin{array}{l}\text { Very } \\
\text { often } \\
(\%)\end{array}$ & $\begin{array}{l}\text { Often } \\
(\%)\end{array}$ & $\begin{array}{l}\text { Some- } \\
\text { times } \\
(\%)\end{array}$ & $\begin{array}{l}\text { Seldom } \\
(\%)\end{array}$ & $\begin{array}{l}\text { Never } \\
(\%)\end{array}$ & $\begin{array}{l}\text { Don't know/ } \\
\text { not relevant } \\
(\%)\end{array}$ \\
\hline $\begin{array}{l}\text { Simple spoken communication such as } \\
\text { telephoning and conversations }\end{array}$ & 17 & 21 & 38 & 22 & 2 & $<1$ \\
$\begin{array}{l}\text { Demanding spoken communication such as } \\
\text { making presentations, negotiating, press } \\
\text { conferences }\end{array}$ & 7 & 14 & 32 & 25 & 21 & 1 \\
$\begin{array}{l}\text { Simple written communication such as } \\
\text { e-mails, letters, memos }\end{array}$ & 16 & 23 & 41 & 19 & 1 & $<1$ \\
$\begin{array}{l}\text { Demanding written communication such as } \\
\text { reports, white papers and articles }\end{array}$ & 6 & 9 & 30 & 26 & 27 & 1.5 \\
\begin{tabular}{l} 
Reading work-related texts \\
\hline
\end{tabular} & 32 & 31 & 28 & 7 & 1 & 0 \\
\hline
\end{tabular}

$n=751$

Table 7 How often have you experienced misunderstandings, difficulties or problems due to poor English proficiency? From Hellekjær (2010)

\begin{tabular}{lcccccc}
\hline Government ministries & $\begin{array}{l}\text { Very } \\
\text { often } \\
(\%)\end{array}$ & $\begin{array}{l}\text { Often } \\
(\%)\end{array}$ & $\begin{array}{l}\text { Some- } \\
\text { times } \\
(\%)\end{array}$ & $\begin{array}{l}\text { Seldom } \\
(\%)\end{array}$ & $\begin{array}{l}\text { Never } \\
(\%)\end{array}$ & $\begin{array}{l}\text { Don't know/ } \\
\text { not relevant } \\
(\%)\end{array}$ \\
\hline $\begin{array}{l}\text { Simple spoken communication such as } \\
\text { telephoning and conversations }\end{array}$ & 0 & 0 & 6 & 29 & 62 & 2 \\
$\begin{array}{l}\text { Demanding spoken communication such as } \\
\text { making presentations, negotiating, press } \\
\text { conferences }\end{array}$ & $<1$ & $<1$ & 12 & 27 & 42 & 18 \\
$\begin{array}{l}\text { Simple written communication such as } \\
\text { e-mails, letters, memos }\end{array}$ & 0 & $<1$ & 5 & 28 & 64 & 3 \\
$\begin{array}{l}\text { Demanding written communication such as } \\
\text { reports, white papers and articles }\end{array}$ & $<1$ & $<1$ & 8 & 23 & 42 & 27 \\
\begin{tabular}{l} 
Reading work-related texts \\
\hline
\end{tabular} & 0 & 1 & 7 & 32 & 58 & 3 \\
\hline
\end{tabular}

$n=751$

answers in the Don't know/Not relevant category indicate, it might be difficult to ascertain whether difficulties have occurred at all. However, the answers to the open-ended question, as well as Fairway's (2011) interview study, indicate that staff members most likely experience communication problems, and that these might be underestimated."

Although the respondents' comments in the final, open-ended question in Hellekjær's (2007a) survey must be interpreted critically, they do make for interesting reading. On the one hand, many mentioned that their ministry did a quite professional job with English, for instance by using highly competent staff to proofread written documents. They also mention that there are many highly competent users of English available. On the other hand, there were also a number of critical remarks. One issue was that many respondents, including those in managerial positions, consistently overestimated their proficiency: 
I feel that many employees, even at the "highest levels" speak English poorly. Many are convinced that they are fairly proficient, but fail to recognize that everyday English is utterly inadequate in for instance complicated negotiations. This means that we often make fools of ourselves in international relations.

Another adds:

It is a general problem in Norway (I have experienced it myself when hiring) that "everybody" in Norway is convinced that he or she is a more or less fluent speaker of English. They are most definitely not. There is a tremendous difference between Norwegian "school" English and the levels of proficiency acquired from having studied in an English-speaking country or using it over time as a working language.

Yet another mentions that little attention is paid to the English of letters and reports, deplores the lack of quality control, and professes at times to be embarrassed by the results.

To sum up-English is used by the great majority of the ministerial employees, and by many on a daily basis. As can be seen in Table 7, it is difficult to determine whether, and to what extent staff, experience difficulties due to inadequate English proficiency, although comments to the open-ended question give indication of such problems are present. However, the richer, qualitative interview data in Fairway's (2011) follow-up survey cast further light on this issue.

\section{Fairway (2011)}

Fairway's interviewed 13 employees in three (anonymized) state directorates, each of which comprise a number of departments. The directorates, which are subordinated to the ministries, have various assignments: They are often suppliers of services to the population in Norway and function as channels of information and expertise in their given field of work. ${ }^{1}$ They often represent Norway in international organizations such as the European Union, United Nation organisations, and in other transnational activities such as in judicial, humanitarian, and political areas.

While two of the directorates dealt primarily with domestic issues, the third worked internationally. However, the interviews showed that this had little effect on their use of English. One of the respondents explained that this was due to Norway's de facto economic integration into the European Union single market as party to the 1994 European Economic Area agreement. He explains:

The great change occurred in 1992-93 with the EEA agreement. This was the great English shock for the caseworkers in our directorate... suddenly my pile of documents was all in English!

Another supported this, saying that for similar reasons "... $70 \%$ of what I write needs to be in English."

During the interviews, the respondents initially claimed that they managed reasonably well, especially with other, non-native speakers of English. However, toward the end of the interviews, many of the respondents elaborated on this by telling stories about awkward situations and even failures they had experienced due to poor English.

${ }^{1}$ http://www.regjeringen.no/nb/dep/fad/dok/veiledninger_og_brosjyrer/1993/direktoratsboka/2.html?id= 464832 (Accessed 18.04.11). 
When the English want a change of the wording in a paragraph and you do not hear the difference between the options, you need to ask yourself why. Normally you would think that there is something I do not understand, and that I am stupid. There have been incidents, though, where they have managed to change the wording and I have, in hindsight, understood that the change meant something that I did not understand at the time because my knowledge of English is so limited.

Furthermore, the interviews show that inadequate English can be compounded by poor communication skills, as well as the lack of cultural awareness, in particular in situations where native speakers of English use their advantage to the full:

The English say "this Norwegian suggestion is very good", and you know that the longer they keep on praising your suggestion at one point there comes a but, or a however. When they have been at it for a while they have knocked down your entire suggestion and told you what an amateur you are... One thing is the language, another is the Norwegian culture, which clashes so totally. We are so impolite, straightforward and coarse, and that is an additional aspect to the language issue. Being less Norwegian is as great a challenge as speaking English.

Another informant also touches upon this "Anglophone advantage":

You do notice that the English-speaking representatives win just about every discussion. There are often a lot of Americans you have to discuss with and they have a vocabulary that is out-of-this-world. American lawyers are dreadful, since they deliberately use the most difficult words they can come up with, and use the language as a means of domination... Very few participants dare ask questions, they are afraid to lose face.

Furthermore, the two linguistically proficient informants in Fairway's sample indirectly reveal that there is unmet need for advanced English proficiency. One mentioned that:

I had a management position in another company a few years ago, and they found [my English skills] such a relief_-“Oh, God, can you do this! Great!” There are hardly any jobs at the level on which I have been working where my English skills have not been useful to me.

The other mentioned:

Being able to lead debates in English is particularly challenging, because you need to hear what people are saying, catch a point in mid-air and take it to the next person. I have experienced this as a success many times, since it is a skill very few master. Being able to listen, knowing the language so well that you can hear when something controversial comes up and take it further. I think the criterion of success is to know the language so well that you can listen and respond. This has given me a special position in the directorate, the fact that I master it so well.

Fairway's study elaborates on, and in part explains, the findings from Hellekjær (2010), the rather inconclusive data in Table 7 in particular. First, it confirms that the use of English is ubiquitous. Second, while many respondents initially claim that they manage well in English, during the interviews, they to some extent contradict this by telling stories of awkward incidents involving native speakers of English in particular. Third, the two informants with the highest English proficiency out of the 13 interviewed described how their English skills had been a great career advantage. This indirectly goes to show that 
advanced English skills are much needed, but in short supply. Fourth, the data indicate that communication problems are due to inadequate English proficiency, cultural issues, and inadequate mastery of the communication situation. This brings us to the job advertisement study presented below.

\section{The job advertisement study}

The study presented below examines which professional qualifications are specified in ministerial job advertisements, and to what extent the need for English is specified. As already noted, we are aware that interpretation of the job advertisement data requires some caution, since these would benefit from being analyzed in a wider context, taking into consideration issues such as legal requirements, informal recruitment, expectations, and internal compromises. This has not been possible in the present study.

The civil servant positions advertised were, in descending order, 219 (45\%) required advisors (including senior advisors), followed by 132 (27\%) specifying senior and higher executive officers, and 108 (22\%) mentioning various leadership positions (director, department heads etc.). Of the remaining 22 (about $4 \%$ ), five were for secretaries, trainees, national experts, web editors, and guards.

With regard to the professional qualifications required, $436(86 \%)$ of the positions specified a Master's or equivalent degree, for instance as a lawyer or veterinarian, while one required a PhD. Next, for 13 (7 \%) of the positions, a Bachelor's degree was sufficient, for $13(3 \%)$, an upper secondary school diploma was sufficient, while for 21 (4\%) positions, no education was specified. A more detailed overview of the areas of expertise

Table 8 Overview of advertisements according to area of expertise and of those mentioning English skills

\begin{tabular}{|c|c|c|c|}
\hline $\begin{array}{l}\text { Area of } \\
\text { expertise }\end{array}$ & Advertisements & $\begin{array}{l}\text { Number of advertisements } \\
\text { mentioning English }\end{array}$ & $\begin{array}{l}\text { Percent of advertisements } \\
\text { mentioning English }\end{array}$ \\
\hline Computing & 33 & 10 & 2 \\
\hline Communications & 23 & 9 & 2 \\
\hline Economics & 60 & 19 & 4 \\
\hline Social sciences & 19 & 5 & 1 \\
\hline Languages & 4 & 3 & $<1$ \\
\hline Law & 104 & 34 & 7 \\
\hline Natural sciences & 11 & 6 & 2 \\
\hline Technical & 5 & 1 & $<1$ \\
\hline Administration & 63 & 24 & 5 \\
\hline Leadership & 98 & 29 & 6 \\
\hline $\begin{array}{l}\text { Research/ } \\
\text { information }\end{array}$ & 4 & 2 & $<1$ \\
\hline $\begin{array}{l}\text { Human } \\
\text { resources }\end{array}$ & 19 & 0 & 0 \\
\hline Education & 2 & 0 & 0 \\
\hline Security & 2 & 2 & $<1$ \\
\hline Other areas & 23 & 5 & 1 \\
\hline Not specified & 15 & 3 & $<1$ \\
\hline Total & 485 & 152 & 31 \\
\hline
\end{tabular}

$n=485$ 
required, together with the number and percentage of advertisements requiring English is presented in Table 8.

It is worth noting that only four of the $485(<1 \%)$ advertisements specified language degrees. The table also shows that government ministries almost without exception require language in combination with a professional degree, as is also the case in BELF studies that almost invariably show that language skills without a relevant degree are not sufficient. Third, it also reveals the gap between the $89 \%$ of the respondents who use English on a regular basis found in Hellekjær (2010), and the low number, $31 \%$, of the advertisements that explicitly require language skills.

With regard to the non-mention of English skills, 197 (68\%) of the advertisements mention communication skills in general but without specifying language, while $16(3 \%)$ simply mention language skills. It is quite probable that English skills can in many cases be subsumed under these. Still, only 152 (31\%) advertisements mention English skills explicitly. Of these, 112 (24\%) required good English skills, while 37 (8\%) required particularly good English skills.

It would be reasonable to expect that most or all of the $88(18 \%)$ advertisements for positions involving international tasks or relations would explicitly require English skills. Analysis showed that $37(42 \%)$ of the $88(100 \%)$ required good skills, and $17(19 \%)$ particularly good skills. 33 (36\%) of the advertisements did not mention English at all.

To sum up, the main finding from this job advertisement NA is the gap between the number of positions requiring English $31 \%$ and the $89 \%$ who use it at work. Furthermore, closer examination reveals great variation-one might even say inconsistency-as to the extent English skills are specified or not, even when it might seem logical to do so, such as for positions involving international contacts and activities. Finally, and with clear implications for higher education, the analysis also makes it crystal clear that ministerial job advertisements almost exclusively require professional degrees in areas other than language.

\section{Discussion}

The data from Hellekjær (2010) and Fairway (2011) presented above clearly show that English is used on a frequent, often daily basis, and that for some respondents, it involves a large part of their job. Next, that many experience language or communication difficulties is indicated by the many critical comments in the open questions in the ministry survey. Fairway's interviews with directorate staff also provide information about difficulties experienced, or even communication failures in a number of situations. These were due to language or cultural issues, as well as an apparent lack of training in professional communication in English. Third, the data also show that despite the high levels of education among for instance the ministerial respondents, $80 \%$ of these had no formal qualifications in English beyond their upper secondary school course. The job advertisement study explains this by showing that employers invariably advertise for staff with professional qualifications, such as in law, economics, or computer science-in combination with English skills, to the extent that language is mentioned at all (Hellekjær and Hellekjær 2015). Last, and by no means least, the analysis shows an almost dramatic gap between the numbers of advertisements explicitly requiring English skills, $31 \%$, and the $89 \%$ of the ministerial staff who use English regularly on the job. The same gap was also found in a large-scale job advertisement, NA study by Vold and Doetjes (2012). This lack of mention 
raises interesting questions about the status and role of English, along with the need for further investigation.

One reason for the lack of mention might be lack of applicants with occupationally relevant English skills, since professional degrees in Norway rarely include English modules, as indicated by the many ministerial employees having to rely on upper secondary school English. We also know that employers tend to avoid asking for skills that are not readily available to increase the number of applications (Grin et al. 2010). In other words, low supply may lead to low demand. Thus, while employers might be overjoyed when a new employee is highly proficient, for instance due to studying abroad, as was the case with one of the respondents in Fairway's study, their other alternatives are in-service training, sending staff on language courses, or simply relying on the applicants' general English skills and hoping for the best.

Another possible explanation for the lack of mention might well be that there are enough applicants who have lived, worked, or studied in English-speaking countries (e.g., Table 5) to meet the needs for advanced skills. Yet another is that employers simply take English skills for granted, and if necessary, send staff to in-service courses. Indeed, this is a view argued by Duchêne and Heller (2012). Their point is that:

... workers' communicative competences are always valued in the light of what they offer companies. Their skills are only minimally recognized and mostly companies take these skills for granted by constructing them as "natural" (Duchêne and Heller 2012, p. 333).

Duchêne and Heller's arguments dovetail with those of Grin et al. and their claim that when employers decide to specify, or not to specify language skills in a job advertisement, this is a highly conscious decision (2010, pp. 123-134). Just like Duchêne and Heller, they argue that this is because introducing an additional requirement when hiring, such as English skills in combination with a professional degree, can reduce the number of applicants, and/or increase hiring costs. This can perhaps explain why only $31 \%$ of the 485 ministerial job advertisements require English, and why English skills are not mentioned for $36 \%$ of the positions involving international activities and institutions. In other words, a possible interpretation of the data could be that employers tend not to specify language skills to avoid increasing hiring costs, most probably because they do not expect many skilled English users with relevant qualifications to be quite limited. This merits further investigation on the one hand and puts the focus on Norwegian higher education on the other.

It can be mentioned that these findings in the present study largely reflect those of other, international and Norwegian studies. The first is that employers, in business as well as the public sector, need employees with professional degrees in combination with English skills (Ehrenreich 2010a, b; Kvam and Schewe 1984). Second, the language difficulties found in the present study were also found in other studies, in Norway (Hellekjær 2007a, 2012; Hagen et al. 2006), and internationally (Charles 2006; Ehrenreich 2010a, b; Jenkins et al. 2011; Kankaanranta and Louhiala-Salminen 2010; Kankaanranta and Planken 2010; Louhiala-Salminen et al. 2005; Louhiala-Salminen and Kankaanranta 2011; RogersonRevell 2007, 2010; Sweeney and Hua 2010). Third, the difficulties experienced by several of Fairway's not-so-proficient respondents are reflected in several of the BELF studies cited above. Indeed, Fairway's respondents' descriptions of being able to communicate well with others at comparable levels of proficiency, but being overwhelmed and outmaneuvered by native speakers of English who used their cultural and linguistic 
advantages to the full, is a familiar one in ELF/BELF studies. Some ELF/BELF researchers, such as Jenkins et al. (2011), argue the need for native speakers to accommodate themselves to the less proficient. However, in occupational contexts, it is hardly realistic to expect such highly proficient speakers to be willing to concede their linguistic and cultural advantages. Instead, we would argue that this clearly shows the need to improve general and occupational English skills among non-native speakers, in Norway and elsewhere, as well as offer training in how to handle such native-speaker dominance.

\section{Solutions}

We would contend that the Anglophone advantage of the universities in English-speaking countries cannot be countered by merely increasing the number of EM courses and hoping that incidental language learning through exposure to English will sufficiently improve the students' proficiency. As indicated by Arkoudis' (2013) examples from Australia, this does not necessarily work even when students are immersed in an English language environment. Instead, institutions outside the English-speaking countries, such as Norway and the other Nordic countries, need to take their students' future needs seriously enough to systematically offer courses in general and occupational English, as well as in communication skills. More specifically, they need to actively ensure that students taking professional degrees, be it in engineering, economics, law, biology, education, or computer science etc., receive this offer-because it is exactly these students who will need such skills in a professional capacity.

Perhaps the main challenge in this process will be to convince university departments and faculties to devote-or divert-time and resources to English, most probably at the expense of the content subjects. One way of doing this could be to systematically exploit the inherent potential for incidental language learning in the EM courses-in particular of special terminology. In fact, many students already choose EM courses to improve their English since they are aware that they will need this in their future careers (Hellekjær 2007b). An example would be requiring students to make presentations and write papers in English as an obligatory part of the EM course, and as part of the process offering support and instruction from language as well as content specialists.

Another issue that needs to be discussed is whether to supplement these with communication courses, that is to say more general courses comprising the language for, and knowledge about oral occupational communication situations such as meetings, negotiations, giving talks, and debating. With regard to writing, these could comprise the most common genres as well as instruction in translation and terminology.

\section{Conclusion}

To sum up, we would argue that the present study provides a valid picture of the need for English skills among educated professionals. Indeed, the findings of the present study largely underpin Marginson's (2006) claim that American and UK universities have a huge competitive advantage in the ongoing national and global competition between universities due to their placement in English-speaking countries. How formidable an advantage is perhaps best exemplified by the two highly proficient directorate employees in Fairway (2011) who had studied in English-speaking countries and consequently mastered tasks and communication situations that their colleagues found daunting. This implies that unless 
Norwegian and Nordic institutions of higher education systematically address their students' need for advanced occupational English and communication skills beyond offering EM courses, they will fail to address the competitive advantage of their counterparts in English-speaking countries. Moreover, unless these institutions begin working to ensure and enhance their students' English skills and language learning, as mentioned by Arkoudis (2013), this advantage will keep on growing.

The practical decisions about how to implement these proposals will of course have to be made at the institutional level. It is also possible that further research and development work will prove necessary, in particular with regard to the design, running, and assessment of EM courses with integrated language-learning goals. A failure to do so, however, will mean conceding the higher Anglophone ground to institutions in English-speaking countries.

Open Access This article is distributed under the terms of the Creative Commons Attribution 4.0 International License (http://creativecommons.org/licenses/by/4.0/), which permits unrestricted use, distribution, and reproduction in any medium, provided you give appropriate credit to the original author(s) and the source, provide a link to the Creative Commons license, and indicate if changes were made.

\section{References}

Arkoudis, S. (2013). Getting serious about English language standards in higher education. Internationalisation of Higher Education, 2, 69-86.

Bhatia, V. K., \& Bremner, S. (2012). English for business communication. Language Teaching, 45(4), $410-445$.

Bonnet, G. (2004). The assessment of pupil's skills in English in eight European countries 2002. The European network of policy makers for the evaluation of educational systems.

Brecht, R. D., \& Rivers, W. P. (2005). Language needs analysis at the societal level. In M. H. Long (Ed.), Second language needs analysis (pp. 79-104). Cambridge: Cambridge University Press.

Brown, J. D. (2009). Foreign and second language needs analysis. In M. H. Long \& C. Doughty (Eds.), The handbook of language teaching (pp. 269-293). Chichester: Wiley-Blackwell.

Charles, M. (2006). Language matters in global communication. Journal of Business Communication, 44(3), 260-282.

Clifford, R. T., \& Fischer, D. C., Jr. (1990). Foreign language needs in the U. S. Government. Annals of the American Academy of Political and Social Science, 511, 109-121.

Duchêne, A., \& Heller, M. (2012). Language policy in the workplace. In B. Spolsky (Ed.), The Cambridge handook of language policy (pp. 323-334). Cambridge: Cambridge University Press.

Dudley-Evans, T., \& St. John, M. J. (1998). Developments in ESP: A multi-disciplinary approach. Cambridge: Cambridge University Press.

Education First. (2013). The English proficiency index. http://www.ef.co.uk/epi/about-epi/. Accessed 29 May 2014.

Ehrenreich, S. (2010a). English as a business lingua franca in a German multinational corporation. Journal of Business Communication, 47(4), 408-431.

Ehrenreich, S. (2010b). Lingua Franca Englishes in international companies: The state of research and an interim research. Aaa-Arbeiten aus Anglistik und Amerikanistik, 35(1), 7-42.

Fairway, T. (2011). The use of English and foreign languages in Norwegian directorates - challenges in international cooperation. Oslo: University of Oslo.

Graddol, D. (2007). Changing English. Abingdon: Routledge.

Grin, F., Sfreddo, C., \& Vaillancourt, F. (2010). The economics of the multilingual workplace. New York: Routledge.

Gundersen, S. L. (2009). Language management: In multinational companies. Bergen: SNF.

Hagen, S., Davila-Philippon, S., \& Nordgren, B. (2006). ELAN: Effects on the European economy of shortages of foreign language skills in enterprise. London: The UK National Centre for Languages (CiLT).

Hellekjær, G.-O. (2007a). Fremmedspråk i norsk naringsliv - engelsk er ikke nok! [Foreign language use in Norwegian business - English is not enough!]. Halden: Fremmedspråksenteret. 
Hellekjær, G. O. (2007b). The implementation of undergraduate level English medium programs in Norway: An explorative case study. In R. Wilkinson \& V. Zegers (Eds.), Researching content and language integration in higher education (pp. 61-81). Maastricht: Valkhof Pers \& Maastricht University.

Hellekjær, G. O. (2010). Språkmakt og avmakt: bruk av og behov for fremmedspråk $i$ statsforvaltningen [Power and powerlessness: The use of and need for foreign language skills in government minisitries]. Halden: Fremmedspråksenteret.

Hellekjær, G. O. (2012). A survey of English use and needs in Norwegian export firms. Hermes-Journal of Language and Communication Studies, 48, 7-18.

Hellekjær, G. O., \& Hellekjær, A.-I. (2014). Is anglophone complacency a virtue of necessity?: The gap between the need for and supply of occupational second foreign language skills in Norwegian business and government. Scandinavian Journal of Educational Research. doi:10.1080/00313831.2014.904412.

Hellekjær, G. O., \& Hellekjær, A.-I. (2015). A high level of English proficiency is required: How Norwegian government job advertisements reveal the need for communication and EOP courses in Norwegian higher education. In S. Dimova, A. K. Hultgren \& C. Jensen (Eds.), The English language in teaching in European higher education. Berlin: De Gruyter Mouton (forthcoming).

Hellum, B., \& Dypedahl, M. (1998). Business communication and cultural awareness in Norwegian companies. Halden: Østfold University College.

Herzog, M. (2003). Impact of the proficiency scale and the oral proficiency interview on the foreign language program at the Defense Language Institute Foreign Language Center. Foreign Language Annals, 36(4), 566-571.

Hughes, R. (2008). Internationalisation of higher education and language policy. Higher Education Management and Policy, 20(1), 1-18.

Huhta, M. (2010). Language and communication for professional purposes. Finland: Helsinki University of Technology PhD, Yliopistopaino.

Hutchinson, T., \& Waters, A. (1987). English for specific purposes: A learning centred approach. Cambridge: Cambridge University Press.

Jasso-Aguilar, R. (2005). Sources, methods and triangulation in needs analysis: A critical perespective in a case study of Waikiki hotel mails. In M. H. Long (Ed.), Second language needs analysis (pp. 127-168). Cambridge: Cambridge University Press.

Jenkins, J., Cogo, A., \& Dewey, M. (2011). Review of developments in research into English as a lingua franca. Language Teaching, 44(3), 281-315.

Kankaanranta, A., \& Louhiala-Salminen, L. (2010). "English?—Oh, it's just work!”: A study of BELF users' perceptions. English for Specific Purposes, 29, 204-209.

Kankaanranta, A., \& Planken, B. (2010). BELF competence as business knowledge of internationally operating business pofessionals. Journal of Business Communication, 47(4), 380-407.

Kvam, S., \& Schewe, T. (1984). Tyskkunnskaper i Norsk Naringsliv: En Analyse av Behov og Etterspørsel [German skills in Norwegian business: An analysis of supply and demand]. Halden: Østfold Distriktshøgskole.

Leppänen, S., Nikula, T., \& Kääntä L. (Eds.) (2008). Kolmas kotimainen: Lähikuvia englannin käytöstä Suomessa. [The Third Domestic Language: Case Studies on the Use of English in Finland] Helsinki: Suomalaisen Kirjallisuuden Seura. [Tietolipas 224].

Lett, J. A. (2005). Foreign language needs assessment in the US military. In M. H. Long (Ed.), Second language needs analysis (pp. 105-124). Cambridge: Cambridge University Press.

Lie, U., \& Skjoldmo, S. (1982). Behovet for fremmedspråkkompetanse i naringslivet [The need for foreign language skills in business]. Bergen: Universitetet i Bergen/Hordaland Lektorlag.

Long, M. H. (2005). Second language needs analysis. Cambridge: Cambridge University Press.

Louhiala-Salminen, L., Charles, M., \& Kankaanranta, A. (2005). English as a lingua franca in Nordic corporate mergers: Two case companies. English for Specific Purposes, 25, 401-421.

Louhiala-Salminen, L., \& Kankaanranta, A. (2011). Professional communication in a global business context: The notion of global communicative competence. IEEE Transactions on Professional Communication, 54(3), 244-262.

Marginson, S. (2006). Dynamics of national and global competition in higher education. Higher Education, $52(1), 1-39$.

Munby, J. (1978). Communicative syllabus design: a sociolinguistic model for defining the content of purpose-specific language programmes. Cambridge: Cambridge University Press.

Norges Handelshøyskole. (1973). Siviløkonomers bruk av fremmedspråk [Economists use of foreign languages]. Bergen: Norges Handelshøyskole.

Reeves, N., \& Wright, C. (1998). Linguistic auditing. Clevedon: Multilingual Matters.

Richterich, R., \& Chancerel, J.-L. (1978). Identifying the needs of adults learning a foreign language. Strasbourg: Council of Europe. 
Rindal, U. (2010). Constructing identity with L2: Pronunciation and attitudes among Norwegian learners of English1. Journal of Sociolinguistics, 14(2), 240-261.

Rogerson-Revell, P. (2007). Using english for international business: A European case studt. English for Specific Purposes, 26, 103-120.

Rogerson-Revell, P. (2010). Can you spell that for us nonnative speakers? Journal of Business Communication, 47(4), 432-454.

Saarinen, T., \& Ursin, J. (2012). Dominant and emerging approaches in the study of higher education policy change. Studies in Higher Education, 37(2), 143-156.

Shadish, W. R., Cook, T. D., \& Campbell, D. T. (2002). Experimental and quasi-experimental designs for generalized causal inference. Boston: Houghton Mifflin.

Sweeney, E., \& Hua, Z. (2010). Accommodatng towards your audience. Journal of Business Communication, 47(4), 477-504.

Tare, M. (2006). Assessing the foreign language needs of the department of homeland security. Journal of Homeland Security and Emergency Management, 3(1), 1-9.

Teddlie, C., \& Tashakkori, A. (2009). Foundations of mixed methods research: integrating quantitative and qualitative approaches in the social and behavioral sciences. Los Angeles: SAGE.

Välimaa, J., \& Hoffman, D. (2008). Knowledge society discourse and higher education. Higher Education, $56(3), 265-285$.

Vold, E. T., \& Doetjes, G. (2012). Fremmedspråk i norsk arbeidsliv: gapet mellom behov og etterspørsel. Acta Didactica Norge, 6(1), 1-19. 